\title{
Prey-switching by Cassin's auklet Ptychoramphus aleuticus reveals seasonal climate-related cycles of Euphausia pacifica and Thysanoessa spinifera
}

\author{
Christine L. Abraham*, William J. Sydeman \\ Marine Ecology Division, PRBO Conservation Science, 4990 Shoreline Highway, Stinson Beach, California 94970, USA
}

\begin{abstract}
Euphausia pacifica and Thysanoessa spinifera comprise a substantial proportion of the diet of Cassin's auklet Ptychoramphus aleuticus in the Gulf of the Farallones, California. Ocean climate variability has been linked to fluctuations in euphausiid abundance and life-history parameters. We tested the hypothesis that seasonal patterns of prey use by auklets correspond to withinseason variation in upwelling and sea surface temperature (SST), by comparing the proportion (by number) of E. pacifica and T. spinifera in auklet diet samples obtained during the chick-rearing period to SST and an upwelling index (UI) over 11 years. We found that the proportion of E. pacifica adults in auklet diet decreased over the chick-rearing period, and increased with increasing UI and decreasing SST. We detected curvature in the relationship between adult E. pacifica and UI, with $E$. pacifica increasing to a point and decreasing thereafter. T. spinifera in auklet diet showed an increase over the chick-rearing period, but no relationships were detected with UI or SST. Mass of individual adult E. pacifica increased with increasing UI and decreasing SST. We detected moderate curvature in the relationship between mass of individual adult T. spinifera and SST. The proportion of E. pacifica juveniles in auklet diet did not change seasonally and was not related to UI or SST, while the proportion of $T$. spinifera juveniles in auklet diet increased seasonally and with increases in UI. Seasonal changes in the ingestion of euphausiids by auklets appeared to be affected by ocean climate variability; however, prey-selection via a shift in foraging location or competition with other marine predators are alternative valid explanations. This study highlighted the utility of using top marine predators to sample prey availability, thereby complementing traditional net sampling procedures for determining the distribution and abundance of euphausiids in marine systems.
\end{abstract}

KEY WORDS: Cassin's auklet · Diet · Euphausiids · Euphausia pacifica · Thysanoessa spinifera · Seasonal variation $\cdot$ Upwelling $\cdot$ Sea surface temperature

Resale or republication not permitted without written consent of the publisher

\section{INTRODUCTION}

Euphausiid crustaceans are important components of zooplankton communities in the north Pacific Ocean. Euphausia pacifica is typically the most abundant euphausiid within a zooplankton assemblage throughout its range, which extends from the California Current to Japan (Mauchline \& Fisher 1969, Brinton 1976). In some regions (Japan: Odate 1979; British Columbia: Fulton \& LeBrasseur 1984), E. pacifica is harvested by commercial fisheries. Thysanoessa spinifera is found in the northeast Pacific from the Gulf of Alaska south to Baja California (Brinton 1976, Summers 1993).

In the California Current System (CCS), Euphausia pacifica and Thysanoessa spinifera are the most abundant euphausiids of the outer continental shelfslope region (Brinton 1976, Tanasichuk 1998a,b, Marinovic et al. 2002, Feinberg \& Peterson 2003, Dorman et al. 2005). E. pacifica is considered the more 'oceanic' species, whereas $T$. spinifera is distributed on the shelf (Brinton 1976, Brinton \& Townsend 2003, Feinberg \& 
Peterson 2003, Lu et al. 2003, Dorman 2005). In regions of distributional overlap, E. pacifica is approximately 100 times more abundant than T. spinifera (Brinton \& Townsend 2003, Feinberg \& Peterson 2003), but there is spatial (latitudinal) and temporal (inter-annual) variability in the relative abundance of these species (Brinton 1962, Feinberg \& Peterson 2003). Previous studies have documented distributional contractions and expansions in response to El Niño/La Niña Southern Oscillation (ENSO) events (Brinton 1981, Marinovic et al. 2002). At longer time scales, E. pacifica was inversely related to inter-decadal ocean warming of the Pacific Decadal Oscillation (PDO) (Brinton \& Townsend 2003), but no relationships were established for T. spinifera.

Although some euphausiid life-history, population, and reproductive characteristics have been related to within-season ocean climate conditions (e.g. the timing and duration of upwelling), many euphausiidoceanographic relationships remain unclear (e.g. Tanasichuk 1998a,b). For example, off British Columbia, Canada, despite spatial associations with upwelling cells in the region, Mackas et al. (2001) found that euphausiid abundance was lower under strong upwelling conditions. Off California and Oregon, Euphausia pacifica reproduction was linked to the seasonal onset of upwelling (Brinton 1976, Feinberg \& Peterson 2003). Some authors have cited that peak reproduction may actually occur during periods of relaxation that often follow strong upwelling events, whereas others have reported year-round spawning (Lindley 1978, Smith \& Adams 1988, Dorman et al. 2005). While the population biology and reproductive ecology of $E$. pacifica has been relatively well-studied in the CCS, these life-cycle parameters of Thysanoessa spinifera are less well known (but see Youngbluth 1976, Smith \& Adams 1988, Marinovic et al. 2002). In addition, rarely have within-season variations in euphausiid abundance and reproductive dynamics been examined in relation to upwelling and other oceanographic processes.

The Gulf of the Farallones (GOF), off central California, is a variable, highly productive region of the central CCS. Upwelling from the Point Arena to Point Reyes region is a dominant physical process here (Schwing et al. 2000). The timing, strength, and duration of upwelling between years is variable. Within each year, the 'upwelling season' is often, but not always, marked by a significant decline in sea surface temperature (SST). In our study, we addressed the hypothesis that the timing and intensity of upwelling and corresponding changes in SST influences the availability of euphausiids to Cassin's auklet in the GOF. We predicted that if upwelling is weak or the initiation of upwelling late, euphausiid production and hence contribution to auklet diet may be reduced or delayed. Furthermore, we hypothesized that there are species-specific prey responses to variable upwelling and SST conditions owing to the different habitats that these species inhabit in the region.

To sample euphausiids over a period of months within each year, we used a biological sampling device. The Cassin's auklet Ptychorhamphus aleuticus is a zooplanktivorous marine bird endemic to the CCS and Gulf of Alaska (Manuwal \& Thorensen 1993). In the central CCS, auklets forage mostly on euphausiids (Abraham \& Sydeman 2004), whereas in the northern CCS/transition zone they consume mostly large calanoid copepods (Bertram et al. 2001, Hedd et al. 2002). During breeding, auklets in the GOF make long foraging trips (often $\sim 60 \mathrm{~km}$ from the colony) (PRBO unpubl. data). They forage via wing-propelled pursuit diving to depths of up to $50 \mathrm{~m}$ (Burger \& Powell 1990). In the GOF, auklet timing of breeding is initiated earlier with increased ingestion of Euphausia pacifica, whereas offspring production is positively correlated with the ingestion of Thysanoessa spinifera (Abraham \& Sydeman 2004). Herein, we extend previous analyses of auklet diet as an indicator of E. pacifica and T. spinifera availability, by examining patterns of within-season variability in diet composition. Specifically, we tested the hypothesis that seasonal patterns of prey use (diet composition, age structure, and body mass) by auklets correspond to within-season variation in the timing and magnitude of upwelling and resultant SST.

\section{MATERIALS AND METHODS}

Study area. This study took place at Southeast Farallon Island (SEFI), California, over 11 yr from 1994 to 2004. SEFI, located $42 \mathrm{~km}$ west of San Francisco, is the largest multi-species seabird colony in the USA (excluding Alaska). Primary terrestrial nesting habitat includes an extensive marine terrace, with the remainder of the island consisting of cliffs and rock faces. This granitic island ( 44 ha) provides suitable breeding habitat for 12 species of ground, cliff, and cavity-nesting seabirds (Ainley \& Boekelheide 1990, Sydeman et al. 2001). SEFI is situated on the continental shelf, approximately $8 \mathrm{~km}$ from the shelf break (200 $\mathrm{m}$ isobath). During the breeding season, Farallon auklets forage mostly to the northwest of SEFI and as far as Cordell Bank, a shallow seamount located $\sim 60 \mathrm{~km}$ to the north (Yen et al. 2004).

Oceanographic measurements. We obtained SST at SEFI each day for the duration of the study (for details see Abraham \& Sydeman 2004). We obtained daily 
indices of upwelling (Bakun's Upwelling Index) from NOAA Pacific Fisheries Environmental Laboratory (www.pfeg.noaa.gov/products/PFEL/modeled/indices /PFELindices.html) (Bakun 1973, Schwing et al. 1996). We computed the mean daily upwelling index (UI) (using the average of daily UI values at $36^{\circ} \mathrm{N}$ and $39^{\circ} \mathrm{N}$ ) for analyses; the Farallones are located at $37^{\circ} 42^{\prime} \mathrm{N}, 123^{\circ} 00^{\prime} \mathrm{W}$ (approximately half way between $36^{\circ} \mathrm{N}$ and $39^{\circ} \mathrm{N}$ ), and therefore, UI at these latitudes encompass the foraging ambit of the auklets (Yen et al. 2004).

Seasonal patterns of euphausiids in auklet diet. The availability of euphausiids in the GOF was indexed by examining the prey brought to the colony by adult auklets provisioning dependent offspring (Ainley et al. 1996, Sydeman et al. 1997, 2001, Abraham \& Sydeman 2004). Cassin's auklets forage in the upper $\sim 50 \mathrm{~m}$ of the water column (Burger \& Powell 1990) and likely forage for their nestlings late in the day before returning to the nest site after dark. Undigested prey are brought back to the colony by parent auklets in a 'gular pouch' (Speich \& Manuwal 1974). Each adult makes at most 1 nightly visit to the nest site; therefore, each bolus of food delivered represents the total amount of food delivered by that parent $\mathrm{d}^{-1}$. The contents of each pouch regurgitation was considered a sample. We attempted to obtain 10 regurgitations $\mathrm{wk}^{-1}$ throughout the chick-rearing period (around mid-May to midAugust), but the sampling period varied each year depending on the timing and duration of auklet reproduction (Table 1). Laboratory analysis (species identification, enumeration, mass measurements and age classifications) for all years was performed by M. Gal- braith at the Institute of Ocean Sciences (Sidney, British Columbia).

As an index of relative abundance, we used the proportional prey composition (by number) of juveniles and adults for each species, averaged by date of collection. Although percent diet composition by mass is commonly used to report trophic relationships, the percent diet composition of Euphausia pacifica and Thysanoessa spinifera by mass and by number are highly correlated (Abraham \& Sydeman 2004), indicating that measurements for prey contribution by mass and number would be similar for the entire data set. Only dates with $\geq 3$ samples collected were analyzed. Annually, the euphausiids E. pacifica and T. spinifera comprise about $77 \%$ (by number, range 62 to $90 \%$ ) of the diet (Abraham \& Sydeman 2004). Although they do consume juveniles (e.g. Adams et al. 2004), SEFI auklets primarily take adults. For analysis of individual adult prey mass, we used the average mass ind. ${ }^{-1}$ (mass of given prey species in sample / no. of ind. of that species in sample); this was also averaged by date of diet collection. Diet composition data were available for $11 \mathrm{yr}, 1994$ to 2004, and individual adult mass data were available for 10 yr, 1994 to 2003.

Statistical analysis. To investigate seasonal variation in euphausiid availability, mass, and reproduction (as provided by auklet dietary indices) relative to ocean climate (UI and SST), we calculated average UI and SST for periods of 30 and $90 \mathrm{~d}$ prior to each diet collection date; $30 \mathrm{~d}$ averages were intended to represent 'short-term' ocean climate conditions, whereas $90 \mathrm{~d}$ averages were intended to represent 'longer-term' ocean climate conditions. Euphausia pacifica and

Table 1. Start and end dates (Day-of-year in parentheses), total period of diet collection, number of days of diet collection, number of diet samples analyzed, and mean $( \pm$ SE) sea surface temperature (SST) of Southeast Farallon Island during March for each year of the study. Only collection days with $\geq 3$ diet samples collected were analyzed for composition; only days with $\geq 3$ diet samples containing either adult Euphausia pacifica or Thysanoessa spinifera were analyzed for mean adult mass

\begin{tabular}{|c|c|c|c|c|c|c|}
\hline Year & Start date & End date & $\begin{array}{l}\text { Period of } \\
\text { collection } \\
\text { (d) }\end{array}$ & $\begin{array}{l}\text { No. d } \\
\text { analysed }\end{array}$ & $\begin{array}{l}\text { No. samples } \\
\text { for diet } \\
\text { composition }\end{array}$ & $\begin{array}{c}\text { March SST } \\
\left({ }^{\circ} \mathrm{C}\right)\end{array}$ \\
\hline 1994 & May 17 (137) & Aug 25 (237) & 100 & 10 & 82 & $13.2 \pm 0.08$ \\
\hline 1995 & June 16 (167) & July 22 (203) & 36 & 6 & 78 & $13.6 \pm 0.10$ \\
\hline 1996 & June 6 (158) & July 19 (201) & 43 & 8 & 108 & $12.9 \pm 0.15$ \\
\hline 1997 & May 15 (135) & June 27 (178) & 43 & 7 & 80 & $10.5 \pm 0.13$ \\
\hline 1998 & July 14 (195) & Aug 11 (223) & 28 & 9 & 81 & $13.2 \pm 0.10$ \\
\hline 1999 & May 6 (126) & Aug 16 (228) & 102 & 9 & 107 & $10.9 \pm 0.06$ \\
\hline 2000 & May $22(143)$ & June 29 (181) & 38 & 8 & 89 & $11.1 \pm 0.18$ \\
\hline 2001 & May 15 (135) & Aug 23 (235) & 100 & 14 & 113 & $11.8 \pm 0.06$ \\
\hline 2002 & April 23 (113) & Aug 25 (237) & 124 & 19 & 141 & $11.2 \pm 0.14$ \\
\hline 2003 & May 23 (143) & Aug 8 (220) & 77 & 14 & 110 & $12.1 \pm 0.11$ \\
\hline 2004 & May 23 (144) & July 30 (212) & 68 & 10 & 85 & $11.9 \pm 0.05$ \\
\hline Mean & May 25 (146) & Aug 2 (214) & 69 & 10 & 98 & ${ }^{\mathrm{a}} 11.8( \pm 0.03)$ \\
\hline Total & & & & 114 & 1074 & \\
\hline
\end{tabular}


Thysanoessa spinifera may reach adulthood within 3 to 4 mo after spawning ( 11 $\mathrm{mm}$ in length) (Brinton 1976, Tanasichuk 1998a,b). Therefore, the lags chosen fall within this developmental period, and represent oceanographic conditions 'early' and 'late' in euphausiid development.

We used multiple linear regression to examine the effect of UI or SST on abundance in diet (availability) and mass, for each euphausiid species and age class (juvenile or adult). We controlled for the linear effect of sampling date and the categorical effect of year in all analyses by entering these variables in all regression models. Statistical analyses were performed using STATA (version 7.0), and significance was assumed when $p<0.05$. Results of significant ocean climate effects on euphausiids in linear regression models were illustrated using 'added variable plots', where values were adjusted for date and year effects. Nonlinear relationships have been hypothesized for small fish in relation to upwelling (e.g. Cury \& Roy 1989). Therefore, we also tested for curvilinear relationships separately by including a quadratic term for UI or SST in each model. All models included a weighting variable (square root of $n$, where $\mathrm{n}$ are the number of diet samples per date). Because these analyses are largely exploratory in nature, we did not account for the potential problem of simultaneous multiple tests (e.g. Botsford \& Lawrence 2002, Abraham \& Sydeman 2004).

All proportional values were transformed prior to analyses using the following 'logit' equation: $\mathrm{p}^{\prime}=\ln [\mathrm{p} /(1-\mathrm{p})]$, where $\mathrm{p}^{\prime}$ is the transformed proportion and $\mathrm{p}$ is the original proportion (STATA: release 8, StataCorp). Prior to transformation, proportional values of 0 (e.g. where a sample contained $0 \%$ of a species) were replaced with values representing half the difference between 0 and the next highest value. Proportional values of 1 (e.g. where a sample contained $100 \%$ of a species) were replaced with values representing half the difference between 1 and the next lowest value (the logit transformation described above is undefined when $\mathrm{p}$ equals 0 or 1). Calculated replacement values used are therefore reflective of the minimums and maximums $(>0$ or $<1)$ of observed proportional data.

\section{RESULTS}

\section{Seasonal variation in UI and SST}

Generally, SST and UI follow relatively predictable seasonal patterns: with the onset of upwelling in the spring, SST decreases (Fig. 1). However, the timing of upwelling and its amplitude and duration (and corre-
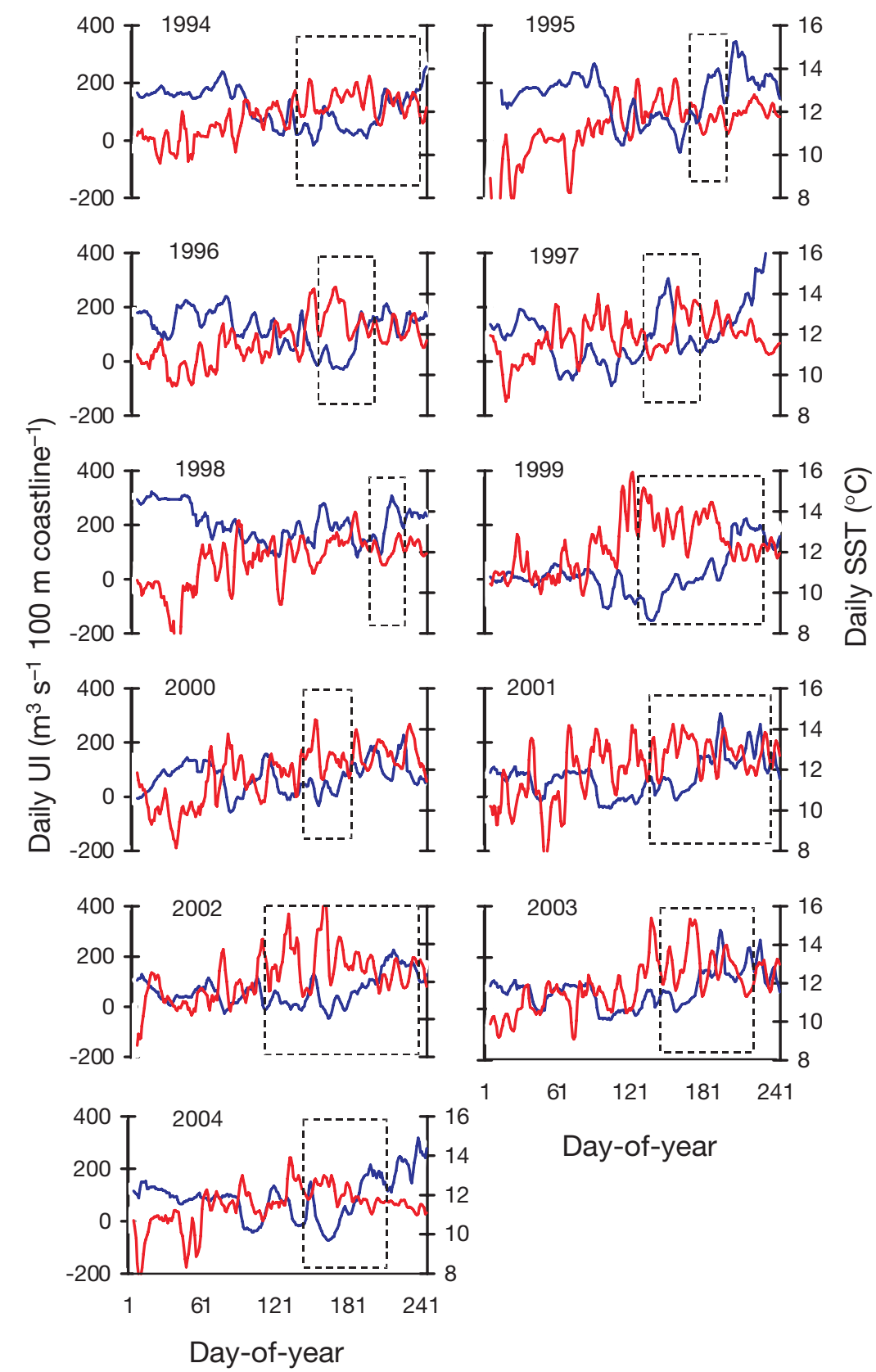

Day-of-year

Fig. 1. Five-day moving averages of daily values of upwelling index (UI, red lines) and Southeast Farallon Island sea surface temperature (SST, blue lines) from January to August, 1994 to 2004; $y$ - and $z$-axes were scaled to display maximum variability in data; dashed boxes: period of diet collection 
sponding changes in SST) were variable within and between years. For example, 1997 began as a typical year, with upwelling increasing (and SST decreasing) from January through to approximately mid-March. Upwelling then declined steadily and remained relatively low until approximately the end of May, after which it increased again. This decline in upwelling in 1997 corresponded to the beginning of the 1997 to 1998 El Niño (ENSO) event in the region. In the El Niño year of 1998, upwelling was very low in winter and did not reach intense summertime peaks as observed in other years, such as during La Niña in 1999. Due to this variability and the interaction between timing and amplitude, it was difficult to categorize years that were not obvious deviations from average conditions.

March is typically the month when auklets initiate reproductive efforts (mean date of egg-laying of first clutches is 13 April: PRBO unpubl. data; auklet egg formation requires $\sim 2$ wk: Roudybush et al. 1979). Timing of breeding also determined when collection of diet samples began each year. With the exception of March 1997 (which began cooler than average, but shortly preceded the strong 1997 to 98 El Niño event), March SST was generally warmer between 1994 and 1998 than the long-term (1926 to 2004) average, and was generally cooler than or close to the long-term average between 1999 and 2004 (Table 1). This pattern corresponded with the presumed phase shift of the PDO from warm to cold conditions in 1999 (Peterson \& Schwing 2003).

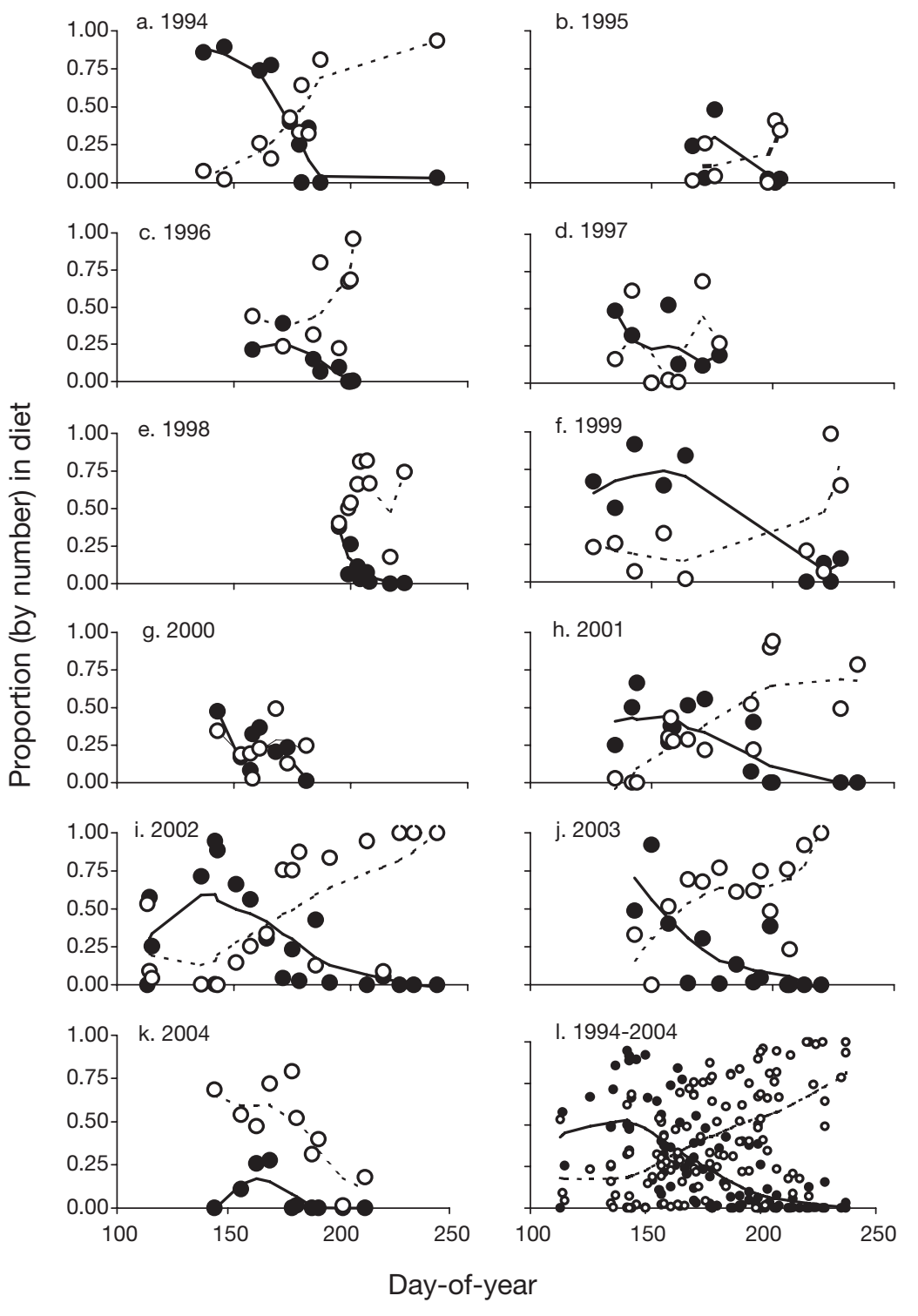

Fig. 2. Euphausia pacifica (O) and Thysanoessa spinifera (O). Mean proportion (by number) of adults in auklet Ptychorampus aleuticus diet on each day of sampling, 1994 to 2004. Locally weighted regression lines (bandwidth $=0.9 ;$ E. pacifica $=$ solid lines,$T$. spinifera $=$ dashed lines $)$ included to illustrate trends

\section{Effects of date and ocean climate on euphausiids in auklet diet}

Adult euphausiids in auklet diet

Of the Euphausia pacifica and Thysanoessa spinifera taken by auklets over the $11 \mathrm{yr}$, an average of 93 and $80 \%$, respectively, were adults. In 5 out of $11 \mathrm{yr}$ (1994, 1999, and 2001 to 2003), the pattern of prey use followed a consistent pattern, with adult $E$. pacifica decreasing and T. spinifera increasing during the progression of the chick-rearing period each year (Fig. 2). The timing of this switch in prey use was variable: regression lines crossed between Dayof-year 150 and 200 (corresponding to 30 May and 19 July), depending on year. The pattern of switching from adult E. pacifica to $T$. spinifera is also illustrated for all years combined (Fig. 2l), demonstrating the generality of this pattern.

The ingestion of Euphausia pacifica decreased over the chick-rearing period (Table 2). At the $30 \mathrm{~d}$ lag E. pacifica showed a significant increase with increasing UI and a significant decrease with increasing SST (Table 2, Fig. 3a,b). There were no significant 
Table 2. Linear relationships between proportion of adult Euphausia pacifica and Thysanoessa spinifera in auklet diet and ocean climate, within seasons. Time period represents no. of days over which upwelling index or sea surface temperature was averaged prior to each date of diet collection. $\beta$ : linear regression coefficient. Text in bold: $\mathrm{p} \leq 0.05$

\begin{tabular}{|c|c|c|c|c|c|c|c|c|}
\hline & \multirow{2}{*}{$\begin{array}{l}\text { Time period } \\
\text { (d) }\end{array}$} & \multicolumn{3}{|c|}{ Ocean climate } & \multicolumn{3}{|c|}{ Date } & \multirow[t]{2}{*}{ Model $\mathrm{R}^{2}$} \\
\hline & & $\beta$ & $t$ & $\mathrm{p}$ & $\beta$ & $t$ & $\mathrm{p}$ & \\
\hline \multicolumn{9}{|c|}{ E. pacifica } \\
\hline \multirow[t]{2}{*}{ UI } & 0 to 30 & 0.0256 & 3.11 & 0.002 & -0.079 & -7.94 & 0.000 & 0.55 \\
\hline & 0 to 90 & 0.0277 & 1.59 & 0.115 & -0.11 & -6.57 & 0.000 & 0.52 \\
\hline \multirow[t]{2}{*}{ SST } & 0 to 30 & -1.25 & -2.29 & 0.024 & -0.06 & -3.98 & 0.000 & 0.54 \\
\hline & 0 to 90 & -0.539 & -0.51 & 0.614 & -0.086 & -7.51 & 0.000 & 0.51 \\
\hline \multicolumn{9}{|c|}{ T. spinifera } \\
\hline \multirow[t]{2}{*}{ UI } & 0 to 30 & 0.0107 & 1.58 & 0.117 & 0.053 & 6.40 & 0.000 & 0.39 \\
\hline & 0 to 90 & 0.0146 & 1.05 & 0.297 & 0.038 & 2.83 & 0.006 & 0.38 \\
\hline \multirow[t]{2}{*}{ SST } & 0 to 30 & -0.505 & -1.14 & 0.257 & 0.060 & 4.82 & 0.000 & 0.38 \\
\hline & 0 to 90 & -0.644 & -0.76 & 0.449 & 0.052 & 5.78 & 0.000 & 0.38 \\
\hline
\end{tabular}

relationships with SST or UI at the 90 d lag. Significant curvature was detected for E. pacifica at the $90 \mathrm{~d}$ lag of UI (Table 3); E. pacifica initially increased with upwelling, but then decreased as upwelling became vigorous. The peak of the curve occurred at a UI value of $146 \mathrm{~m}^{3} \mathrm{~s}^{-1} 100 \mathrm{~m}$ of coastline $\mathrm{e}^{-1}$, indicating that this magnitude of upwelling may represent an upper threshold of tolerance of E. pacifica to strong upwelling conditions. The ingestion of Thysanoessa spinifera increased over the chick-rearing period (Table 2), but there were no significant relationships with UI or SST (Table 2).

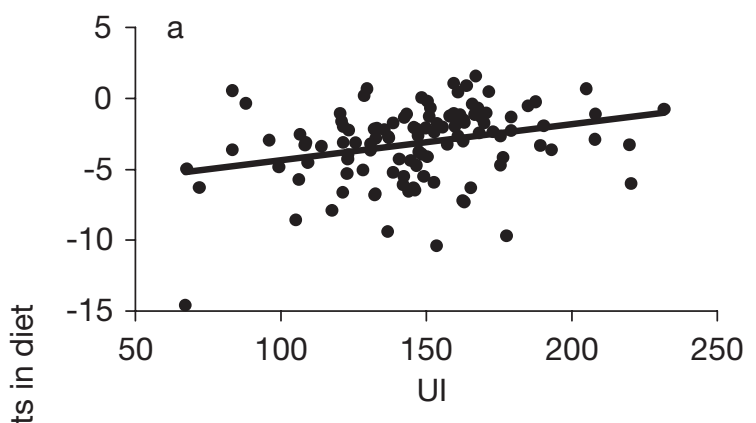

There was no effect of date on the mass of individual adult Euphausia pacifica taken by auklets (all $t<1.2$, $\mathrm{p}>0.1$ ) (Fig. 4). The average mass of E. pacifica increased slightly with UI within the $30 \mathrm{~d}(\beta=0.0002$, $t=1.70, \mathrm{p}=0.096)$ and $90 \mathrm{~d}(\beta=0.0004, t=1.81, \mathrm{p}=$ $0.077)$ lags. The mass of E. pacifica decreased significantly with increasing SST at the $30 \mathrm{~d}$ lag $(\beta=$ $-0.015, t=-2.00, \mathrm{p}=0.051$ ) (Fig. $3 \mathrm{c}$ ). There was no curvature detected for the relationship between mass of individual adult E. pacifica and UI or SST (all $t<0.3$, $\mathrm{p}>0.1$ ). There was no effect of date on Thysanoessa spinifera mass (all $t<0.8, \mathrm{p}>0.1$ ) (Fig. 4). Mass of $T$. spinifera decreased slightly with increasing SST at the $90 \mathrm{~d}$ lag period $(\beta=-0.0154, t=-1.83, \mathrm{p}=0.072)$. Moderate curvature was detected for mass of $T$. spinifera only for the relationship with the $30 \mathrm{~d}$ SST average $\left(\beta_{1}=0.15, t=1.76, \mathrm{p}=0.083 ; \beta_{2}=-0.007, t=-1.80\right.$, $\mathrm{p}=0.076) ; T$. spinifera mass initially increased with SST, but then decreased as SST continued to increase throughout the chick-rearing period. The peak of the curve occurred at the SST value of $11.4^{\circ} \mathrm{C}$.

\section{Juvenile euphausiids in auklet diet}

In contrast to adults, there was no consistent pattern in the take of juveniles of either species in auklet diet. Euphausia pacifica juveniles comprised a very small proportion of auklet diet $(<2 \%)$, whereas ingestion of juvenile Thysanoessa spinifera was more substantial ( 10\%) (Fig. 5). There were no relationships with date or ocean climate variable for juvenile E. pacifica (all $t<0.6, \mathrm{p}>0.1$ ). In contrast, the ingestion of juvenile $T$. spinifera increased with UI at the $30 \mathrm{~d}$ lag $(\beta=0.0238$, $t=2.97, \mathrm{p}=0.004)$ and with date $(\beta=0.02, t=2.09$, $\mathrm{p}=0.039$ ) (Fig. 6). Curvature was not detected for juveniles of either species in relation to UI or SST (all
Fig. 3. Euphausia pacifica. Added-variable plots showing (a) logit-transformed proportion of adults in auklet Ptychoramphus aleuticus diet and UI, (b) logit-transformed proportion of adults in auklet diet and SST, and (c) adult mass and UI. Values adjusted for date and year effects. UI and SST are 0 to $30 \mathrm{~d}$ lags 
Table 3. Curvilinear relationships between proportion of adult Euphausia pacifica and Thysanoessa spinifera in auklet diet and ocean climate, within seasons. $\beta$ : linear and quadratic regression coefficients $(\beta)$. Text in bold: $(p \leq 0.05)$

\begin{tabular}{|c|c|c|c|c|c|c|c|c|c|c|c|}
\hline & \multirow{2}{*}{$\begin{array}{l}\text { Time period } \\
\text { (d) }\end{array}$} & \multicolumn{6}{|c|}{ Ocean climate } & \multirow{2}{*}{\multicolumn{3}{|c|}{ Date }} & \multirow[t]{2}{*}{ Model R } \\
\hline & & $\beta$ & $\begin{array}{c}\text { Linear } \\
t\end{array}$ & $\mathrm{p}$ & $\beta$ & $\begin{array}{c}\text { Quadrat } \\
t\end{array}$ & $\mathrm{p}$ & $\beta$ & & & \\
\hline \multicolumn{12}{|c|}{ E. pacifica } \\
\hline UI & $\begin{array}{l}0 \text { to } 30 \\
0 \text { to } 90\end{array}$ & $\begin{array}{l}0.090 \\
0.204\end{array}$ & $\begin{array}{l}2.23 \\
2.81\end{array}$ & $\begin{array}{l}0.028 \\
0.006\end{array}$ & $\begin{array}{l}-0.0002 \\
-\mathbf{0 . 0 0 0 7}\end{array}$ & $\begin{array}{l}-1.63 \\
-2.50\end{array}$ & $\begin{array}{l}0.106 \\
\mathbf{0 . 0 1 4}\end{array}$ & $\begin{array}{l}-0.081 \\
-0.106\end{array}$ & $\begin{array}{l}-8.10 \\
-6.48\end{array}$ & $\begin{array}{l}0.000 \\
0.000\end{array}$ & $\begin{array}{l}0.57 \\
0.55\end{array}$ \\
\hline SST & $\begin{array}{l}0 \text { to } 30 \\
0 \text { to } 90\end{array}$ & $\begin{array}{c}1.73 \\
12.617\end{array}$ & $\begin{array}{l}0.18 \\
0.55\end{array}$ & $\begin{array}{l}0.858 \\
0.583\end{array}$ & $\begin{array}{l}-0.129 \\
-0.579\end{array}$ & $\begin{array}{l}-0.31 \\
-0.57\end{array}$ & $\begin{array}{l}0.758 \\
0.567\end{array}$ & $\begin{array}{l}-0.060 \\
-0.086\end{array}$ & $\begin{array}{l}-3.86 \\
-7.49\end{array}$ & $\begin{array}{l}0.000 \\
0.000\end{array}$ & $\begin{array}{l}0.54 \\
0.51\end{array}$ \\
\hline \multicolumn{12}{|c|}{ T. spinifera } \\
\hline UI & $\begin{array}{l}0 \text { to } 30 \\
0 \text { to } 90\end{array}$ & $\begin{array}{r}0.046 \\
-0.020\end{array}$ & $\begin{array}{r}1.38 \\
-0.33\end{array}$ & $\begin{array}{l}0.171 \\
0.743\end{array}$ & $\begin{array}{c}-0.0001 \\
0.00014\end{array}$ & $\begin{array}{r}-1.08 \\
0.59\end{array}$ & $\begin{array}{l}0.282 \\
0.556\end{array}$ & $\begin{array}{l}0.052 \\
0.037\end{array}$ & $\begin{array}{l}6.31 \\
2.75\end{array}$ & $\begin{array}{l}0.000 \\
0.007\end{array}$ & $\begin{array}{l}0.40 \\
0.39\end{array}$ \\
\hline SST & $\begin{array}{l}0 \text { to } 30 \\
0 \text { to } 90\end{array}$ & $\begin{array}{l}-2.54 \\
-2.462\end{array}$ & $\begin{array}{l}-0.32 \\
-0.13\end{array}$ & $\begin{array}{l}0.747 \\
0.893\end{array}$ & $\begin{array}{l}0.088 \\
0.080\end{array}$ & $\begin{array}{l}0.26 \\
0.10\end{array}$ & $\begin{array}{l}0.796 \\
0.921\end{array}$ & $\begin{array}{l}0.059 \\
0.0525\end{array}$ & $\begin{array}{l}4.69 \\
5.71\end{array}$ & $\begin{array}{l}0.000 \\
0.000\end{array}$ & $\begin{array}{l}0.38 \\
0.38\end{array}$ \\
\hline
\end{tabular}

$\mathrm{p}>0.1$ for quadratic terms). In most years where juvenile T. spinifera was present, any peak observed in abundance typically followed the peak in UI.

\section{DISCUSSION}

\section{Seasonal ocean climate-euphausiid} relationships: the prey's perspective

In the CCS in general, Euphausia pacifica is typically characterized as 'oceanic', and is most often associated with the outer continental shelf and shelf break, while Thysanoessa spinifera is characterized as 'neritic', and is most associated with on-shelf and near-shore environments (Brinton 1976, Feinberg \& Peterson 2003, Lu et al. 2003, Dorman et al. 2005). However, it is clear that there is spatial and temporal variability in these general characteristics that results in considerable overlap in the cross-shelf distribution of these species.

In the GOF, Cassin's auklets forage mostly over the outer continental shelf and shelf break/slope waters (Yen et al. 2004) where they take both species in varying amounts. Indeed, our results indicated consistent within-season variation in the relative abundance of these adult euphausiids in auklet diet, with Euphausia pacifica decreasing and Thysanoessa spinifera increasing over the chick-rearing period. This temporal effect was more pronounced than the ocean climate effect for both euphausiid species (Table 2). Notably, the seasonal 'crossing pattern' shown was most evident in certain years (e.g. 1994, 1999, and 2001 to 2003; see Fig. 2); these years were generally characterized by
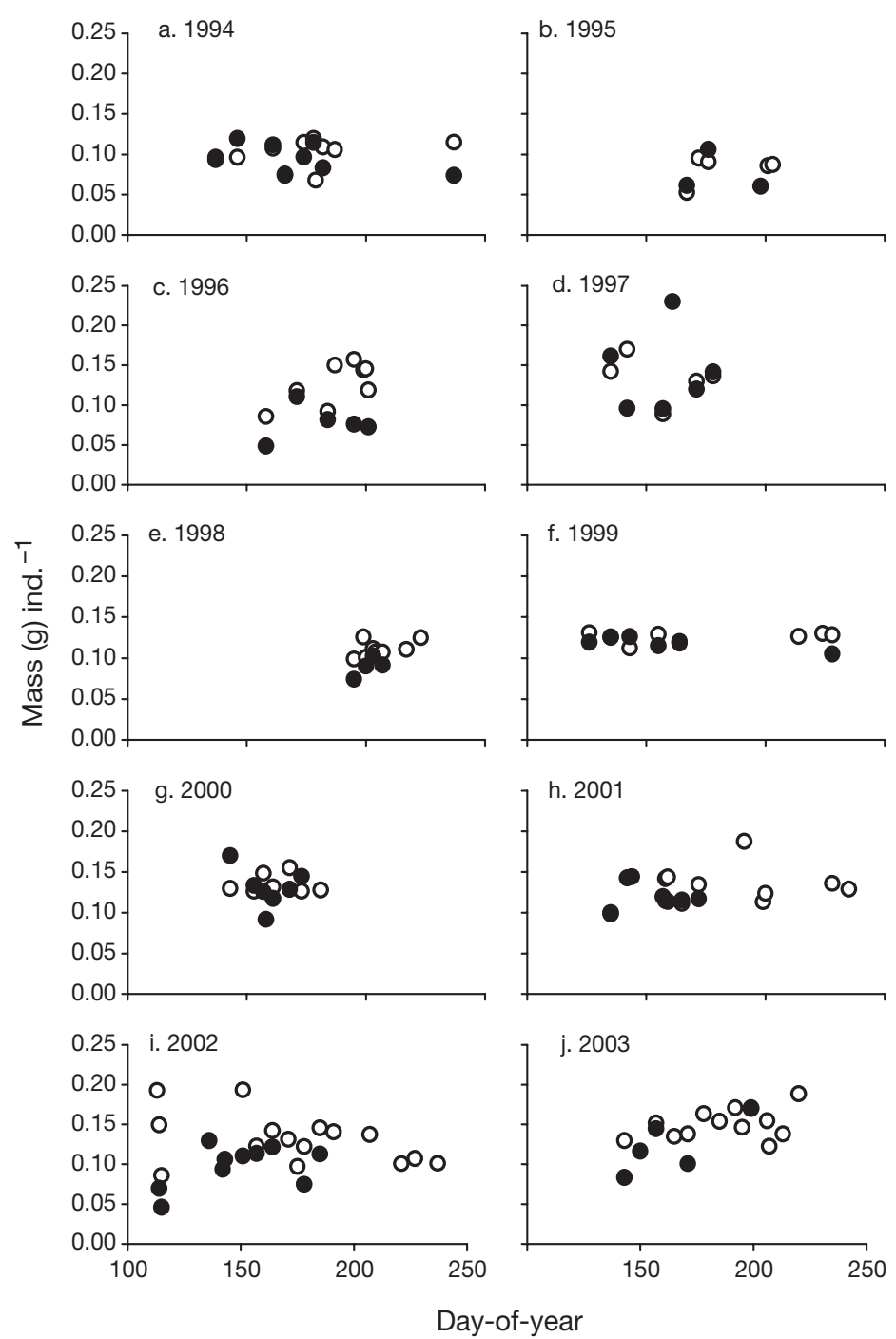

Fig. 4. Euphausia pacifica (@) and Thysanoessa spinifera (0). Mean mass (g) per individual adult in auklet Ptychoramphus aleuticus diet on each day of sampling, 1994 to 2003 


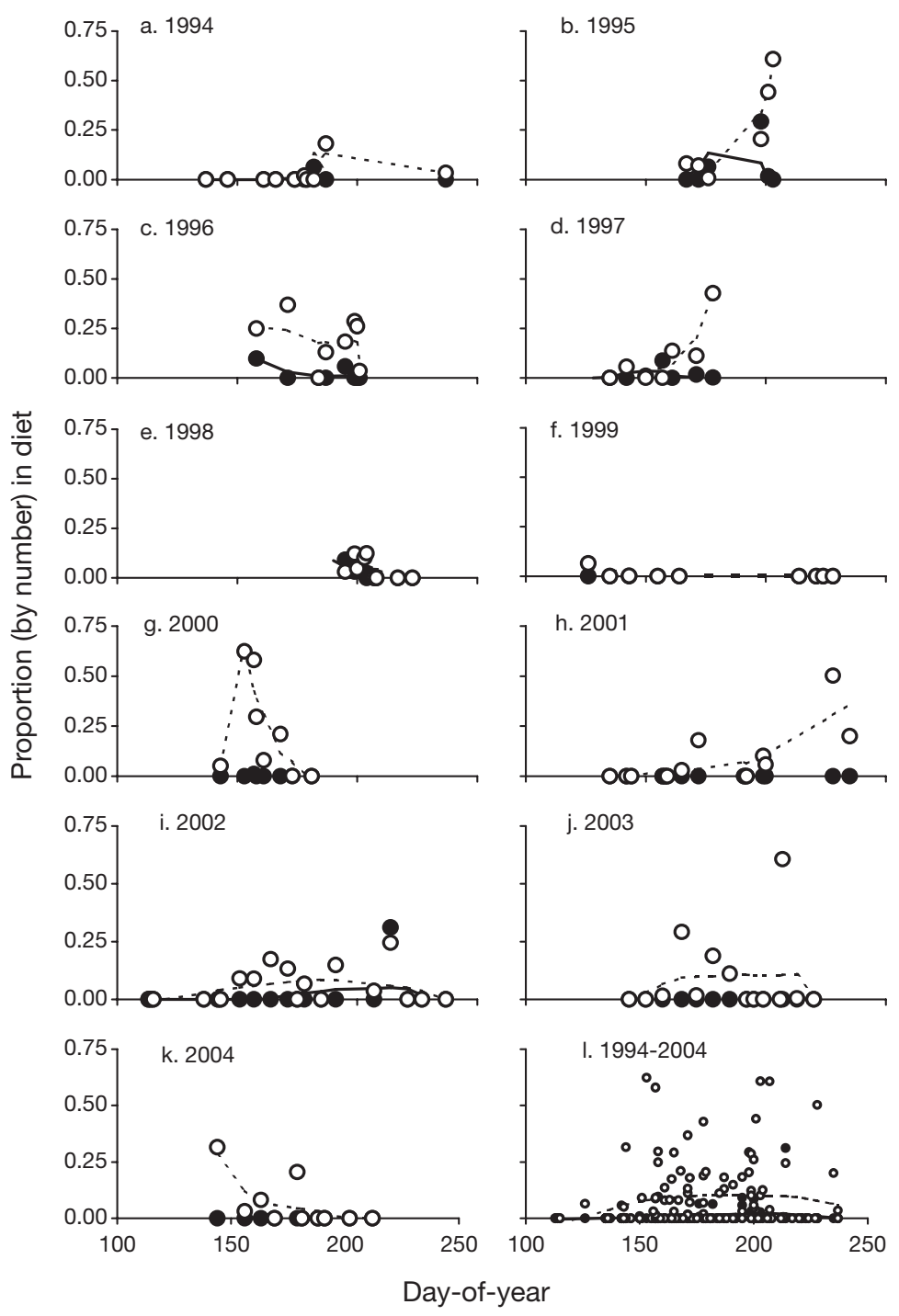

Fig. 5. Euphausia pacifica (@) and Thysanoessa spinifera (0). Mean proportion (by number) of juveniles in auklet Ptychoramphus aleuticus diet on each day of sampling, 1994 to 2004 . Locally weighted regression lines (bandwidth $=0.9):$ E. pacifica, solid lines; $T$. spinifera, dashed lines
Similar seasonal shifts in the pattern of prey use by Cassin's auklet have been reported elsewhere in the CCS. On Triangle Island, British Columbia, Bertram et al. (2001) reported within-season shifts from calanoid copepods to euphausiids and/or fish. Off southern California, where Euphausia pacifica and Thysanoessa spinifera are also the most abundant prey species in auklet diet, Adams et al. (2004) reported a seasonal shift from E. pacifica to T. spinifera in some years, but not others.

The switch in prey ingestion from Euphausia pacifica to Thysanoessa spinifera occurs between the beginning of June and end of July (between Day-of-year 150 and 200, depending on year) (Fig. 2). For all years, upwelling during this period declined with date $(\beta=-0.812 \pm 0.27, t=$ -2.99, $\mathrm{p}=0.003)$ and increasing SST $(\beta=$ $0.029 \pm 0.003, t=9.11, \mathrm{p}<0.001)$. Therefore, the switch in prey may be attributed to the decrease in adult E. pacifica in the auklet's foraging range associated with a decline in seasonal upwelling (Table 2).

With a higher UI (and lower SST), the relative abundance of adult Euphausia pacifica in auklet diet increased to a threshold level, after which it began to decline. The take of E. pacifica was related to ocean climate averaged over 30 and $90 \mathrm{~d}$ prior to collection dates. Cury \& Roy (1989) described curvilinear relationships between upwelling intensity and pelagic fish recruitment, and termed this an 'optimal environmental window'. In other words, there exists a range of upwelling conditions that are favorable for these pelagic organisms, bounded by those that are unfavorable. In relation to our study, as upwelling colder ocean temperatures, early onset of the auklet breeding season, and high reproductive success (PRBO unpubl. data). In the years when prey-switching was less evident (1995 to 1998, 2000, and 2004), the proportional take of E. pacifica was lower and sampling (dependent on the onset of the auklet breeding season) was conducted later within each season. While we were not able to detect such obvious crossing patterns during these years, we suspect that this may have been more likely due to the effect of late sampling (which reflected the timing of auklet breeding) rather than to a natural phenomena in euphausiid availability. However, it probably also partly reflected reduced availability of E. pacifica during these years (Abraham \& Sydeman 2004). increased in spring, resultant phytoplankton blooms likely provided enhanced feeding conditions for euphausiids; this may have facilitated reproductive behavior later in the season as adults grew and matured. However, if the magnitude of upwelling continued to increase to intense levels and/or if upwelling stabilized at relatively high levels (persistent upwelling), phytoplankton concentrations may have dissipated due to turbulence, resulting in deteriorating feeding conditions and/or advection of euphausiids offshore where they would become unavailable to auklets.

Our results supported other studies that have suggested that strong and persistent Ekman transport contributes to the offshore displacement of euphausiid larvae (e.g. Lu et al. 2003). Off the west coast of Van- 


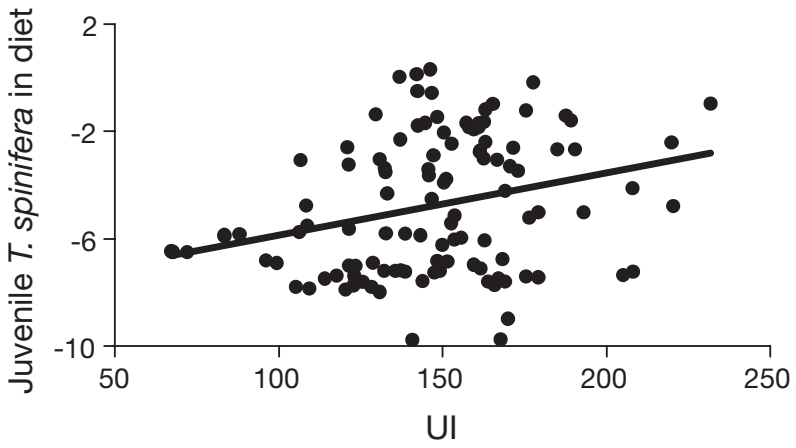

Fig. 6. Thysanoessa spinifera. Added-variable plot showing logit-transformed proportion of juveniles in auklet Ptychoramphus aleuticus diet and UI (0 to $30 \mathrm{~d}$ lag). Values adjusted for date and year effects

couver Island, British Columbia, Lu et al. (2003) suggested that anomalously strong upwelling conditions resulted in partial recruitment failure of euphausiids. In contrast, in Barkley Sound, British Columbia, Tanasichuk (1998a) reported both strong recruitment and high productivity of Euphausia pacifica associated with intense upwelling conditions. Brinton (1976) also observed enhanced spawning of E. pacifica concurrent with significant upwelling events. However, these studies did not test for non-linear relationships. Other studies have suggested that euphausiids take advantage of relaxation periods (Lindley 1978, Smith \& Adams 1988, Dorman et al. 2005) when feeding 'strata' (phytoplankton aggregations) may develop, thereby improving foraging opportunities. Relaxation events and warmer surface waters may also be related to gonadal development and 'surface swarming' behavior (Smith \& Adams 1988).

Our finding that the mass of individual adult Euphausia pacifica increased with increases in upwelling (and reductions in SST) is difficult to interpret. Mass may be influenced by somatic growth, varying cohorts moving through the population, and/or by accumulation of reproductive materials (eggs, spermatophores, etc.). It seems likely that increased upwelling and the subsequent increase in nutrients in the surface layer directly influences either growth or sexual maturation of individual E. pacifica. It is not surprising that we did not observe any relationships for E. pacifica juveniles, as they comprised a very small portion of the diet.

The fact that we did not observe any relationships between adult Thysanoessa spinifera in the diet or mass and upwelling or SST is puzzling given the strong seasonal increase in proportion of both adult and juvenile T. spinifera over the chick-rearing period, the relationships observed for Euphausia pacifica and ocean climate, and the fact that $T$. spinifera is suppos- edly the species most strongly associated with upwelling (Ainley et al. 1996). Summers (1993) reported that $T$. spinifera may reach adult length in less than $2 \mathrm{mo}$; therefore, the increase in juvenile $T$. spinifera over the breeding season and with the $30 \mathrm{~d}$ lag in UI suggests that $T$. spinifera reproductive behavior is associated with upwelling. It is also possible that adult T. spinifera are less responsive to fluctuating conditions or respond more slowly to upwelling than adult $E$. pacifica. The strong seasonal increase in T. spinifera in the diet does not support the idea that $T$. spinifera is available to auklets all year regardless of patterns of ocean climate variability. It is also possible that T. spinifera was responding to ocean climate variables unrelated to those investigated in our study, but we find that unlikely as SST as a proxy for ocean climate integrates a variety of oceanographic processes.

\section{Seasonal ocean climate-euphausiid relationships: the predator's perspective}

There are several additional explanations for the seasonal shift in auklet prey ingestion that may be explained by behavior of the birds. These interpretations are not mutually exclusive from those invoking oceanographic processes. Related to behavior of the auklets is the possibility is that there is active prey selection of a preferred prey species. In the Antarctic, Hill et al. (1996) compared euphausiids in the diet of Macaroni Penguins Eudyptes chrysolophus to net samples and found that penguins were consuming larger prey and more adult females than were collected in the nets. This result was ascribed both to predator selection of large female krill along with more effective net avoidance/escape capabilities of male krill. Croll et al. (2005) found that blue whales Balaenoptera musculus fed on a higher proportion of large euphausiids than were available in Monterey Bay, and concluded that blue whales targeted aggregations comprised mainly of large adults.

Active prey selection during the auklet breeding season may occur due to changing energetic requirements and/or nutritional demands of either parents or young. If prey selection is occurring, auklets may prefer to take Euphausia pacifica (most abundant) for as long as they are available in the environment, after which they switch to the next most abundant prey (Thysanoessa spinifera) by default. Alternatively, auklets may prefer T. spinifera and forage for them as soon as they become available in the season, irrespective of the abundance of E. pacifica in the environment. Following this logic, the pattern of ingestion of E. pacifica should be closely related to ocean climate in the first scenario, with the same being true for $T$. spinifera in 
the second scenario. Our results lend support to the first scenario, as the abundance of adult E. pacifica in the diet was more closely related to ocean climate than was T. spinifera. Moreover, body condition of longlived seabirds often declines between the early and late portion of the chick-rearing season (Jones 1994, Kitaysky et al. 1999, Moe et al. 2002, Lormee et al. 2003). This decrease has been attributed to an increase in the nutritional demands of growing nestlings, and a corresponding increase in parental foraging effort required to meet those demands.

Assuming that the diet of parents is similar to that of nestlings, auklets may prefer to forage on the considerably more abundant ( 100-fold; Brinton \& Townsend 2003) Euphausia pacifica earlier in the nestling season to facilitate the accumulation of energy reserves for chick-rearing. Active prey selection would depend on auklets being capable of distinguishing between prey species within or among aggregations, and to make appropriate adjustments in foraging location or depth as necessary. These adjustments would be made within limits, however, as auklets are constrained in terms of the maximum distance they can forage from the colony (observed up to $\sim 60 \mathrm{~km}$ from SEFI), the maximum depth of dives $(\sim 50 \mathrm{~m}$; Burger \& Powell $1990)$ and the number of nightly visits to the nest site (maximum of 1 per adult). Croll et al. (2005) found that most spatially distinct patches of euphausiids sampled in Monterey Bay were composed primarily of either E. pacifica or Thysanoessa spinifera, and suggested that single or dominant-species aggregations may be relatively easy to identify by predators. However, $E$. pacifica and $T$. spinifera are similar in energy density (E. pacifica $=4800 \mathrm{cal} \mathrm{g}^{-1}, T$. spinifera $=4700$ to $5200 \mathrm{cal} \mathrm{g}^{-1}$; Mooney 1999), suggesting that the seasonal switch from E. pacifica to $T$. spinifera alone would not result in a significant change in the value of prey consumed by adults or meal loads delivered to nestlings.

Another possibility is passive prey-selection via active selection of foraging location. In this case, it is not the prey per se that are being targeted. Auklets may prefer to forage along the shelf-break (and up to Cordell Bank, $\sim 60 \mathrm{~km}$ north of the colony), where the more oceanic Euphausia pacifica are likely to be abundant early in the season when nestling demands are relatively low. Yen et al. (2004) reported that Cassin's auklets were found in relatively high densities close to the shelf-break (200 m isobath) near both Cordell Bank and the Farallones; their surveys were conducted mainly in May when auklets forage primarily on $E$. pacifica. Under 'passive prey-selection' (as explained in this study), when auklets are faced with increasing nutritional demands of nestlings, they may reduce their foraging ambit and feed upon Thysanoessa spinifera, the neritic species that may be located closer to the colony. Auklets, like all seabirds, are central place foragers during breeding (Orians \& Pearson 1979): they may become even more tied to the colony as the chick-rearing season progresses, and this may lead to passive prey-switching relative to foraging location. In other words, parents may become constrained in terms of the distance they can travel to foraging grounds when they have to work harder to raise progressively larger chicks. Therefore, this strategy may be the result of a tradeoff, with parents trying to balance their own energetic and nutritional demands against those of the offspring. In this case, E. pacifica is (passively) the preferred prey species and its use is closely related to ocean climate, but $T$. spinifera is passively selected later in the season to reduce costs of foraging for dependent offspring.

Euphausia pacifica adults were taken in larger amounts early in the chick-rearing seasons of 1994, 1999, and 2001 to 2003 (Figs. 2 \& 7a). These years were generally characterized by cool March SST, early initiation of auklet breeding, and a high occurrence of 'double brooding', or attempts to raise a second chick after a successful first nesting attempt (PRBO unpubl. data). Double-brooding is rare in seabirds (Hamer et al. 2002) and has only been reported for Cassin's auklets that breed in relatively low latitudes in the CCS. Only in years of double-brooding is auklet productivity exceptionally high (PRBO unpubl. data). Other years in our time series were generally characterized by warmer March SST, delayed breeding (by an average of $\sim 3 \mathrm{wk}$ ), and a low incidence of double-brooding (PRBO unpubl. data). Therefore, the period of chickrearing and diet collection was prolonged in the ' $\mathrm{Cool}^{\prime}$ years, providing enhanced sampling of the seasonal switch in prey use, which demonstrates the importance of E. pacifica to auklet reproductive output. In warm years (Figs. $2 \& 7$ ), breeding was delayed and while E. pacifica adults were also used early in the chickrearing season, this was to a lesser extent than in cool years $(\sim 12 \%$ of the diet in warm/late years versus $\sim 36 \%$ in cool/early years). Thysanoessa spinifera adults were used in similar amounts in warm versus cool years $(\sim 45 \%$ of the diet in warm years versus $\sim 42 \%$ in cool years). Moreover, Ainley et al. (1996) showed that adult auklet stomachs contained mostly E. pacifica in the pre-breeding and early chick-rearing season, and $T$. spinifera later in the chick-rearing period; therefore the diet and pattern of prey consumption by adults and chicks appears to be similar. If E. pacifica availability in the pre-breeding period is reduced in warmer years, there may be a delay in the amount of time it takes adult auklets to reach breeding condition, resulting in a delay in breeding and, ultimately, poor reproductive performance. Indeed, Abra- 
ham \& Sydeman (2004) demonstrated that earlier breeding was associated with a higher proportion of E. pacifica in auklet diet, and concluded that E. pacifica availability was an important factor influencing the timing of breeding.

Another explanation is that auklets switch to Thysanoessa spinifera later in the season due to increasing seasonal competition for Euphausia pacifica by other predators such as migrating Pacific hake Merluccious productus. Pacific hake are the most abundant fish species in the CCS. Ware \& McFarlane (1995) reported that migrating hake account for $61 \%$ of the pelagic biomass. Adult hake undergo an extensive northward migration along the outer shelf in late spring/early summer, from southern and central California to Vancouver Island, British Columbia (Bailey et al. 1982). Results of diet analyses indicate that euphausiids comprise a substantial proportion of Pacific Hake diet (Tanasichuk et al. 1991, Buckley \& Livingston 1997). If hake target E. pacifica as they migrate northward along the central California coast, competition and/or prey depletion may force auklets to move to on-shelf foraging areas where $T$. spinifera is more abundant.

In summary, the seasonal shift in prey use by auklets may be related to (1) spatial and temporal variation in prey availability, influenced by variation in upwelling, (2) a shift in preferred prey and/or foraging range, influenced by energetic constraints faced by the auklets, and (3) avoidance of competition and/or prey

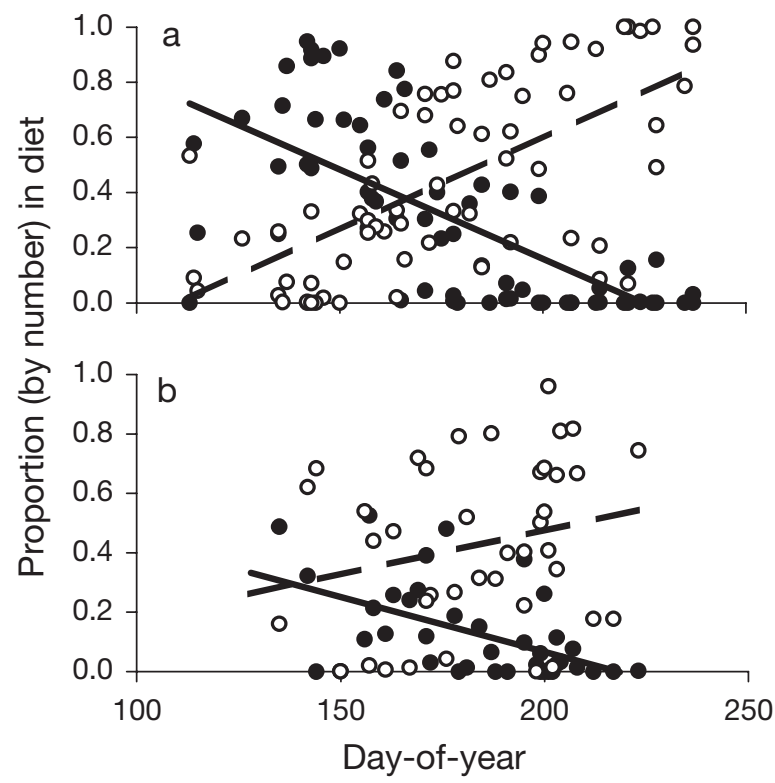

Fig. 7. Euphausia pacifica (๑) and Thysanoessa spinifera (0). Mean proportion (by number) of adults in auklet Ptychoramphus aleuticus diet on each day of sampling in (a) 1994, 1999, and 2001 to 2003, and (b) 1995 to 1998, 2000, and 2004. Linear regression lines: E. pacifica, solid lines; T. spinifera, dashed lines depletion, influenced by Pacific hake and possibly other highly migratory krill-eating predators (e.g. baleanopterid whales).

\section{Implications for monitoring euphausiids in the CCS}

The use of top marine predators to sample and proxy forage fish and zooplankton ('prey') availability has been advanced as a method to complement traditional net sampling procedures for determining the distribution and abundance of these mid-trophic level organisms that are often difficult to study (e.g. Cairns 1987, Montevecchi 1993, Mills et al. 2006). This method has become a featured part of a few marine ecosystem-monitoring programs across the globe (e.g. Convention for the Conservation of Antarctic Marine Living Resources; for more details see www.ccamlr.org). So-called predatorbased sampling (PBS) may be especially important for sampling mid-trophic level organisms that are not caught representatively in nets in regions where there are no standardized net-sampling programs (Mills et al. 2006). Moreover, PBS may complement temporally or spatially restricted net-based sampling at great cost effectiveness. In particular, if PBS is temporally expansive (greater duration of sampling) relative to shipboard net sampling efforts, it may reveal patterns of distribution and abundance that are not apparent in shorterterm studies. For example, using information on the within-season diet of a piscivorous seabird Uria aalge, Miller \& Sydeman (2004) described patterns of rockfish Sebastes spp. abundance in relation to ocean climate that were not apparent at the inter-annual time scale. Similarly, the use of zooplanktivorous seabirds, like auklets, may provide new information on how oceanographic processes affect the distribution, abundance, or reproductive ecology of euphausiids. Because the foraging behavior and diet of marine predators may be restricted with respect to depth and/or range, the investigation of such relationships would be improved by examining a suite of planktivorous predators with various foraging attributes.

Predator-based indices are not without problems (reviewed by Mills et al. 2006). However, there are also numerous benefits in examining the diet of predators as indices of the abundance of prey in the environment. One important reason is that predators cue in on maximum abundances (large aggregations) of prey. For euphausiids, large swarms are patchy and ephemeral in time and space, and thus extraordinarily difficult to sample by station-specific, net-sampling methods. High-density, patchy aggregations are characteristic of euphausiids in the CCS (Smith \& Adams 1988, Brinton \& Townsend 2003), and some of these aggregations appear related to highly ephemeral hydrographic 
features (e.g. upwelling jets) (Huntley et al. 2000). Therefore, annual or seasonal net-based estimates of euphausiid abundance in the CCS may fail to capture the overarching aggregative behavior of these species. As predators dependent on finding and exploiting ephemeral patches of euphausiids in the CCS, auklets appear to provide an index for euphausiid distribution and abundance that will strongly complement net sampling efforts in the region.

Acknowledgements. This study has been made possible by a long-term (1971 to present) cooperative agreement between US Fish and Wildlife Service and PRBO Conservation Science (formerly Point Reyes Bird Observatory). We thank the Farallon biologists and the dozens of field assistants who have contributed to this study over the years. Specifically, we thank N. Nur for his advice on statistical analyses. Four anonymous reviewers contributed excellent suggestions. This is contribution PRBO contribution no. 1213.

\section{LITERATURE CITED}

Abraham CL, Sydeman WJ (2004) Ocean climate, euphausiids, and auklet nesting: inter-annual trends and variation in phenology, diet and growth of a planktivorous seabird, Ptychoramphus aleuticus. Mar Ecol Prog Ser 274:235-250

Adams J, Takekawa JY, Carter HR (2004) Stable foraging areas and variable chick diet in Cassin's auklets (Ptychoramphus aleuticus) off southern California. Can J Zool 82:1578-1595

Ainley DG, Boekelheide RJ (eds) (1990) Seabirds of the Farallon Islands; structure and dynamics of an upwelling system community. Stanford University Press, Stanford, CA

Ainley DG, Spear L, Allen SG (1996) Variation in the diet of Cassin's auklet reveals spatial, seasonal and decadal occurrence patterns of euphausiids off California, USA. Mar Ecol Prog Ser 137:1-10

Bailey KM, Francis RC, Stevens PR (1982) The life history and fishery of Pacific whiting, Merluccius productus. Calif Coop Ocean Fish Investig Rep 23:81-98

Bakun A (1973) Coastal upwelling indices, west coast of North America, 1946-71. NOAA Tech Rep, NMFS SSRF671

Bertram DF, Mackas DL, McKinnell SM (2001) The seasonal cycle revisited: interannual variation and ecosystem consequences. Prog Oceanogr 49:283-307

Botsford LW, Lawrence CA (2002) Patterns of co-variability among California Current chinook salmon, coho salmon, dungeness crab, and physical oceanographic conditions. Prog Oceanogr 53:283-305

Brinton E (1962) The distribution of Pacific euphausiids. Bull Scripps Inst Oceanogr Univ Calif 8:51-270

Brinton E (1976) Population biology of Euphausia pacifica off southern California. Fish Bull 74:733-762

Brinton E (1981) Euphausiid distributions in the California Current during the warm winter-spring of 1977-78, in the context of a 1949-1966 time series. Calif Coop Ocean Fish Investig Rep 22:135-154

Brinton E, Townsend A (2003) Decadal variability in abundances of the dominant euphausiid species in the southern sectors of the California Current. Deep-Sea Res II 50: $2449-2472$
Buckley TW, Livingston PA (1997) Geographic variation in the diet of Pacific hake, with a note on cannibalism. Calif Coop Ocean Fish Investig Rep 38:53-62

Burger AE, Powell DW (1990) Diving depths and diet of Cassin's auklet at Reef Island, British Columbia. Can J Zool 68:1572-1577

Cairns DK (1987) Seabirds as indicators of marine food supplies. Biol Oceanogr 5:261-271

Croll DA, Marinovic B, Benson S, Chavez FP, Black N, Ternullo R, Tershy BR (2005) From wind to whales: trophic links in a coastal upwelling system. Mar Ecol Prog Ser 289:117-130

Cury P, Roy C (1989) Optimal environmental window and pelagic fish recruitment success in upwelling areas. Can J Fish Aquat Sci 46:670-680

Dorman JG, Bollens SM, Slaughter AM (2005) Population biology of euphausiids off northern California and effects of short time-scale wind events on Euphausia pacifica. Mar Ecol Prog Ser 288:183-198

Feinberg LR, Peterson WT (2003) Variability in duration and intensity of euphausiid spawning off central Oregon, 1996-2001. Prog Oceanogr 57:363-379

Fulton J, LeBrasseur R (1984) Euphausiids of the continental shelf and slope of the Pacific coast of Canada. La Mer 22: $268-276$

Hamer KC, Schreiber EA, Burger, J (2002) Breeding biology, life histories and life history-environment interactions in seabirds. In: Schreiber EA, Burger J (eds) Biology of marine birds. CRC Press, Boca Raton, FL, p 217-261

Hedd A, Ryder JL, Cowen LL, Bertram DF (2002) Inter-annual variation in the diet, provisioning and growth of Cassin's auklets at Triangle Island, British Columbia: responses to variation in ocean climate. Mar Ecol Prog Ser 229:221-232

Hill HJ, Nathan PN, Croxall JP, Watkins JL (1996) A comparison of Antarctic krill Euphausia superba caught by nets and taken by macaroni penguins Eudyptes chrysolophus: evidence for selection. Mar Ecol Prog Ser 140:1-11

Huntley ME, González A, Zhu Y, Zhou M, Irigoien X (2000) Zooplankton dynamics in a mesoscale eddy-jet system off California. Mar Ecol Prog Ser 201:165-178

Jones IL (1994) Mass changes of least auklets Aethis pusilla during the breeding season: evidence for programmed mass loss. J Anim Ecol 63:71-78

Kitaysky AS, Wingfield JC, Piatt JF (1999) Dynamics of food availability, body condition and physiological stress reponse in breeding Black-legged Kittiwakes. Funct Ecol 13: $577-584$

Lindley JA (1978) Population dynamics and production of euphausiids. I. Thysanoessa longicaudata in the North Atlantic ocean. Mar Biol 46:121-130

Lormee H, Jouventin P, Trouve C, Chastel O (2003) Sexspecific patterns in baseline corticosterone and body condition changes in breeding red-footed boobies Sula sula. Ibis 145:212-219

Lu B, Mackas DL, Moore DF (2003) Cross-shore separation of adult and juvenile euphausiids in a shelf-break alongshore current. Prog Oceanogr 57:381-404

Mackas DL, Thompson RE, Galbraith M (2001) Changes in the zooplankton community of the British Columbia continental margin, 1985-1999, and their covariation with oceanographic conditions. Can J Fish Aquat Sci 58: 685-702

Manuwal DA, Thoresen AC (1993) Cassin's auklet (Ptychoramphus aleuticus). In: Poole A, Gill F (eds) The Birds of North America, No. 50. The Academy of Natural Sciences, Philadelphia; The American Ornithologists' Union, Washington, DC

Marinovic BB, Croll DA, Gong N, Benson SR, Chavez FP 
(2002) Effects of the 1997-1999 El Niño and La Niña events on the zooplankton abundance and euphausiid community composition within the Monterey Bay coastal upwelling system. Prog Oceanogr 54:265-277

Mauchline J, Fisher LR (1969) The biology of euphausiids. Adv Mar Biol 7:1-454.

Miller AK, Sydeman WJ (2004) Rockfish response to lowfrequency ocean climate change as revealed by the diet of a marine bird over multiple time scales. Mar Ecol Prog Ser 281:207-216

Mills KL, Laidig T, Ralston S, Sydeman WJ (in press) Top predator diet as an indicator of pelagic juvenile rockfish (Sebastes spp.) recruitment in the California Current System, with implications for ecosystem-based fisheries management. Fish Oceanogr

Moe B, Langseth I, Fyhn M, Gabrielsen W, Bech C (2002) Changes in body conditition in breeding kittiwakes Rissa tridactyla. J Avian Biol 33:225-234

Montevecchi WA (1993) Birds as indicators of change in marine prey stocks. In: Furness RW, Greenwood JJD (eds) Birds as monitors of environmental change. Chapman \& Hall, London, p 217-264

Mooney JR (1999) Distribution, energetics and parasites of euphausiids in Prince William Sound, Alaska. MSc thesis, University of Alaska, Fairbanks

Odate K (1979) An euphausiid crustacean exploited along the Sanriku and Joban coast. Bull Tohoku Reg Fish Res Lab 40:15-25

Orians GH, Pearson NE (1979) On the theory of central place foraging. In: Horn DJ, Mitchell RD, Stairs GR (eds) Analysis of ecological systems. Ohio Univeristy Press, Columbus, OH, p 155-177

Peterson WT, Schwing FB (2003) A new climate regime in northeast Pacific ecosystems. Geophys Res Lett 30, doi: 10.1029/2003GL017528

Roudybush TE, Grau CR, Petersen MR, Ainley DG, Hirsch KV, Gilman AP, Patten SM (1979) Yolk formation in some charadriiform birds. Condor 81:293-298

Schwing FB, O'Farrell M, Steger J, Baltz K (1996) Coastal upwelling indices, west coast of North America, 1946-1995. NOAA Tech Memo NMFS SWFC-231

Schwing FB, Moore CS, Ralston S, Sakuma KM (2000) Record coastal upwelling in the California Current in 1999. Calif Coop Ocean Fish Investig Rep 41:148-160

Editorial responsibility: Otto Kinne (Editor-in-Chief), Oldendorf/Luhe, Germany
Smith SE, Adams PB (1988) Daytime surface swarms of Thysanoessa spinifera (Euphausiacea) in the Gulf of the Farallones, California. Bull Mar Sci 42:76-84

Speich S, Manuwal DA (1974) Gular pouch development and population structure of Cassin's auklet. Auk 91:291-306

Summers PL (1993) Life-history, growth and ageing in Thysanoessa spinifera. MS thesis, University of Victoria

Sydeman WJ, Hobson KA, Pyle P, McClaren EB (1997) Trophic relationships among seabirds in central California: combined stable isotope and conventional dietary approach. Condor 99:327-336

Sydeman WJ, Hester MM, Thayer JA, Gress F, Martin P, Buffa J (2001) Climate change, reproductive performance and diet composition of marine birds in the southern California Current System 1969-1997. Prog Oceanogr 49: 309-329

Tanasichuk RW (1998a) Interannual variations in the population biology and productivity of Euphausia pacifica in Barkley Sound, Canada, with special reference to the 1992 and 1993 warm ocean years. Mar Ecol Prog Ser 173: 163-180

Tanasichuk RW (1998b) Interannual variations in the population biology and productivity of Thysanoessa spinifera in Barkley Sound, Canada, with special reference to the 1992 and 1993 warm ocean years. Mar Ecol Prog Ser 173: 181-195

Tanasichuk RW, Ware DM, Shaw WA, McFarlane GA (1991) Variations in the diet, daily ration and feeding periodicity of Pacific hake (Merluccius productus) and spiny dogfish (Squalus acanthuis) off the lower west coast of Vancouver Island. Can J Fish Aquat Sci 48:2112-2128

Ware DM, McFarlane GA (1995) Climate induced changes in Pacific hake (Merluccius productus) abundance and pelagic community interactions in the Vancouver Island Upwelling System. In: Beamish RJ (ed) Climate change and northern fish populations. Can Spec Publ Fish Aquat Sci 121:509-521

Yen P, Sydeman WJ, Hyrenbach KD (2004) Marine bird and cetacean associations with bathymetric habitats and shallow water topographies: implications for trophic transfer and conservation. J Mar Syst 50:79-99

Youngbluth MJ (1976) Vertical distribution and diel vertical migration of euphausiids in the central region of the California Current. Fish Bull 74:925-936

Submitted: July 8, 2005; Accepted: September 29, 2005 Proofs received from author(s): March 16, 2006 